\title{
Fast Food Consumption and Health Status of Students of a University in Sri Lanka
}

\author{
J.M.J.K. Jayasinghe* and L.P.U. De Silva
}

\begin{abstract}
Fast foods have gained popularity in Sri Lanka, especially among the youths and people who have busy lifestyles. University students who stay most of the time away from home tend to consider convenience, availability and style of eating as important factors in fulfilling their food and energy requirement. This situation may lead to have an imbalance in their nutrient status and to increase the risk of diet related non communicable diseases (NCDs). This study identified the factors influencing fast food consumption among students in one of the state universities of Sri Lanka. Moreover, the nutrient compositions of mostly consumed fast foods were analyzed and the current health status of the students was identified. The research was conducted with both online and offline using a questionnaire for which two hundred and five students responded. Around 54\% of the students consumed fast foods more than once a day. Price and taste were the major attributes that determined the selection of fast food. No differences were found between attitude towards fast food consumption and gender, frequency of fast food consumption and nutritional status and body mass index (BMI) and gender. Majority $(70 \%)$ of the students in the faculty were healthy and having a normal BMI (20-21 $\left.\mathrm{kg} / \mathrm{m}^{2}\right)$. Approximately, one quarter $(26 \%)$ of females were underweight and only $65 \%$ of them were normal and healthy. Of the female respondents, $7 \%$ were overweight and $2 \%$ were obese. Among the male students, $79 \%$ were healthy with normal BMI. However, as $12 \%$ were overweight, there is a higher risk
\end{abstract}

Department of Food Science and Technology, Faculty of Applied Sciences, University of Sri Jayewardenepura, Nugegoda, Sri Lanka.

*jcy6199@yahoo.com of affecting them by diet related NCDs. The above findings suggest a need for health education programs that promote healthy eating habits and lifestyle for university students.

Keywords: BMI, Fast food consumption, Nutritional status, Obesity, University students

\section{INTRODUCTION}

Obesity is a chronic disease and defined as abnormal or excessive fat accumulation that presents a risk to human health. World Health Organization (WHO) predicts that about 2.7 billion adults will be overweight and obese by 2025. Obesity rate in Sri Lanka has increased from 5\% in 2008 to $6.8 \%$ in 2014 (WHO, 2014) resulting in an increase in government's health cost. Moreover, $75 \%$ of total deaths in the country are caused by diet related non communicable diseases (NCDs) (WHO, 2014) and nearly 1 in 5 people die prematurely from NCDs.

Increase of body weight is directly linked with excessive calorie intake and lack of physical exercise. When the body mass index (BMI) is in between 25 and 29.9 $\mathrm{kg} / \mathrm{m}^{2}$ they are considered as overweight or pre obese (WHO, 2004). People are obese when the BMI exceeds $30 \mathrm{~kg} / \mathrm{m}^{2}$. There is a strong association between diet and risk of obesity, cardiovascular disease, and certain cancers (Trichopoulou et al., 2003). Obesity 
is associated with diseases (Finer, 2011) such as type 2 diabetes (Pereira et al., 2005), heart disease (Rocha et al., 2012) and hypertension and dyslipidemia (Kearney, 2010). Eating habits and type of foods consumed by the people are determining factors of good health. The World Health Organization promotes healthy diet which is recognized as a main factor in preventing obesity and NCDs across all age groups (WHO, 2014).

Fast food represents food which is quickly prepared and eaten outside the home (Afolabi et al., 2013). Hamburgers, French fries, doughnuts, fried chicken and pizza are considered as typical fast foods (Seo et al., 2011). However, in South Asian countries particularly in Sri Lanka, "Rolls" (fish/ vegetable), "Cutlets" (fish/ vegetable/ egg), "Roti" (vegetable/egg/naan), "Wade", "Pastries", "Patties" and "Buns" (fish/ vegetable) are some prominent types of fast foods. Kearney (2010) showed that fast food contributes a great change in nutrition transition through the composition and structure of healthy traditional diets to westernized diet. Fast foods are convenient and economical for people with busy lifestyles but these foods are high in saturated fat, sugar, salt and energy (Wellard et al., 2012; Wilcox et al., 2013; Almiron-Roig et al., 2013; Roe et al., 2013). Therefore, nutrition transition increases the intake of fat (particularly saturated fat), sugar, sodium, cholesterol and animal products while decreasing the consumption of fiber and unrefined cereals (Afolabi et al., 2013). Greater availability of fast food is positively associated with obesity (Dunn et al., 2012) and considered as one of the major determinant factors of obesity rates (Currie et al., 2010). Fast and convenient nature and lower price have made fast foods more popular and affordable particularly among people in their teens and twenties (Cotti and Teft, 2013, Seo et al., 2011).

During the period of transition from adolescence to young adulthood, many health behaviors are developed and established (Laska et al., 2012). Reorientation of eating behaviors is inevitable with the transition from school to university (El Ansari et al., 2012). The people in their teens and twenties are the most frequent consumers of fast foods (Lee, 2007). The energy and nutritional requirements of young adults are high. However, frequent consumption of fast foods by them may bring negative consequences to their growth and development. High rate of fast food consumption may lead to chronic diseases, including obesity, diabetes and hypertension (Seo et al., 2011). Frequent fast food consumption caused adolescents to feel "westernization of taste", "favoring eating outs" and "liking salty foods" (Sim and Kim, 1993). Arulogun and Owolabi (2011) reported that over $80 \%$ of the university undergraduates in Nigeria consumed fast foods at least once a week. Excessive weight gain has been observed among young adults particularly among university students (Mihalopolous, 2008; Laska et al., 2010,).

Fast foods have been identified as 
one of the major causes for imbalance in dietary patterns leading to a magnification in the diet related NCD risk (Khatib, 2004). Recent other studies on fast food consumption include academic achievements and fast food intake of Japanese and American college students (Kobayashi, 2009); socio- economic determinants of fast food eating among university students in Poland (DanowskaOziewicz et al., 2012); fast food consumption habits of university students in Turkey (Yardimci et al., 2012, Onurlubaş and Yilmaz, 2013); relationship between fast food consumption and BMI among female university students in Saudi Arabia (Alfawaz, 2012) and fast food consumption and dietary self-efficacy of university students in Nigeria (Akindutire and Konwea, 2013). Moreover, Deliens et al., (2013) showed that academic performance is associated with a wide range of weight and health related behaviours due to the fast food consumption. The above studies confirm that fast food consumption of university students has gained higher attention by the health authorities of the particular countries.

Considering the rapid growth of the fast food sector in Sri Lanka, its popularity among teens and potential health risks associated with frequent consumption, designing appropriate nutritional education programs for younger people is important. To carry out such tasks, a good understanding of factors affecting the use of fast foods, their nutritional values, and current nutritional status of young adults should be analyzed. University students represent a major segment among young adults. However, a little is known about eating habits and health status of university students in Sri Lanka.

This study was conducted to identify the product attributes that influence the consumption of fast food, to analyze the nutrient composition of the mostly consumed fast foods, to identify the current nutritional status of the university students and to establish a relationship between the dietary energy content of the popular fast foods and the nutritional status of the university students.

\section{MATERIALS AND METHODS}

Data for this study was collected through a questionnaire distributed among the students of a Sri Lankan university. Population of this study is the undergraduate students in all four years studying in the faculty in OctoberNovember 2013. Prior to the development of the survey questionnaire, an exploratory survey with randomly selected 25 students was conducted in order to identify type of fast foods and the factors that likely influence the consumption of fast food.

In order to assess the nutritional status of the students and their opinions regarding fast food consumption several statistical tests were applied. The following relationships were assessed.

- The place where students live and their nutritional status in terms of BMI using Kruskal Wallis Test.

- The perception towards students' diet 
and their actual growth status using Spearman's Rank Order Correlation.

- Attitudes toward fast food consumption and gender by applying Median Test.

- The frequency of fast food consumption and the growth status using Spearman's Rank Order Correlation.

- BMI and gender by applying Median Test.

- The frequency of fast food consumption and gender by Median test.

Types of fast foods consumed by the respondents were identified through the questionnaire. Four of the mostly consumed fast food items were selected for nutrient composition analysis. Protein, fat, carbohydrate, fiber, moisture, ash and energy content of each food item were determined. All the analyses were performed according to the Standard AOAC, 1980 methods.

All the undergraduate students studying at one of the faculties of this university, by 2013 were eligible for participating in the study. A sample of 205 students was selected to take part in this study. Responses were collected using the pre-tested questionnaire both online and offline. All the students studying Food Science and Technology (120) of this faculty representing all four batches were selected initially and the questionnaire was sent to all of them online through e-mails. The rest (85) were selected within the faculty through their nominations. The data collected were analyzed using SPSS 17.0 with suitable statistical tools.

\section{RESULTS AND DISCUSSION}

\section{Demographics of the Sample}

Characteristics of the respondents are shown in Table 1. The sample was dominated by female respondents $(62 \%)$. Half of the respondents were coming to the university from their homes while $42 \%$ were in boarding houses. Mean BMI values of the male and female students were 21.9 and 20.5 respectively. Mean waist of male and female respondents were reported as 81 and $76 \mathrm{~cm}$ respectively.

According to $\mathrm{WHO}$, there is an increased risk of metabolic complications for men with a waist circumference $\geq 102$ $\mathrm{cm}$ and women with a waist circumference $\geq 88 \mathrm{~cm}$. The results suggest that no male students were found with the waist circumference $\geq 102 \mathrm{~cm}$. However, four female students $(4 \%)$ were found with waist circumference $\geq 88 \mathrm{~cm}$.

The findings shows that the majority (70\%) of respondents are healthy having a normal BMI. Only $30 \%$ of them have a higher risk of contributing to diseases. According to the findings, more than one quarter $(26 \%)$ of female students are underweight and only $65 \%$ of them are normal and healthy. Of the female respondents, $7 \%$ are overweight and $2 \%$ are obese. Among the male students $79 \%$ are healthy with a normal BMI (Figure 1). However, they are associated with a higher risk of diet related NCDs by being overweight (12\%). Underweight percentage is 9 for male respondents while none is in obese state. 
Table 1: Demographic characteristics of respondents

\begin{tabular}{|c|c|c|}
\hline Character & & $\%$ \\
\hline \multirow[t]{2}{*}{ Gender } & Male & 38 \\
\hline & Female & 62 \\
\hline \multirow[t]{4}{*}{ Academic year } & $1^{\text {st }}$ year & 21 \\
\hline & $2^{\text {nd }}$ year & 32 \\
\hline & $3^{\text {rd }}$ year & 35 \\
\hline & $4^{\text {th }}$ year & 12 \\
\hline \multirow{4}{*}{$\begin{array}{l}\text { Current place } \\
\text { of living }\end{array}$} & At home & 50 \\
\hline & $\begin{array}{l}\text { At boarding } \\
\text { house }\end{array}$ & 42 \\
\hline & At the hostel & 7 \\
\hline & Relative's home & 1 \\
\hline \multirow[t]{2}{*}{ Mean age (yrs) } & Male & $23.4 \pm 1.18$ \\
\hline & Female & $23.2 \pm 1.25$ \\
\hline \multirow[t]{2}{*}{ Mean BMI } & Male & $21.94 \pm 2.77$ \\
\hline & Female & $20.56 \pm 3.35$ \\
\hline \multirow{2}{*}{$\begin{array}{l}\text { Mean weight } \\
(\mathrm{kg})\end{array}$} & Male & $64.57 \pm 9.57$ \\
\hline & Female & $52.02 \pm 8.84$ \\
\hline \multirow{2}{*}{$\begin{array}{l}\text { Mean } \\
\text { (m) }\end{array}$} & Male & $1.71 \pm 0.07$ \\
\hline & Female & $1.59 \pm 0.06$ \\
\hline \multirow{2}{*}{$\begin{array}{l}\text { Mean } \\
(\mathrm{cm})\end{array}$} & Male & $81 \pm 5.21$ \\
\hline & Female & $76 \pm 7.19$ \\
\hline
\end{tabular}

Frequency of Fast Food Consumption

It is found out that $54 \%$ of the respondents are daily consumers with $21 \%$ of them consume fast foods more than once a day (Table 2). Therefore, it is evident that fast foods have become part of their daily diet. Other than that, $46 \%$ of respondents do eat fast food, but not regular consumers.

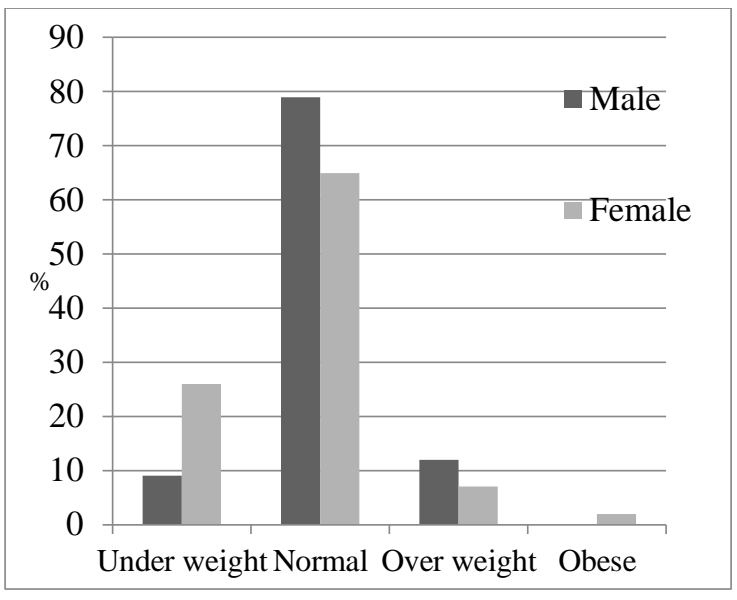

Figure 1: Nutritional status with respect to BMI of male and female students

Table 2: Gender wise differences of frequency of fast food consumption (\%)

\begin{tabular}{lccc}
\hline Frequency & Male & Female & Average \\
\hline 2-3 times a day & 26 & 15 & 21 \\
Once a day & 39 & 27 & 33 \\
4-6 times a week & 15 & 8 & 12 \\
2-3 times a week & 13 & 30 & 21 \\
Once a week & 7 & 15 & 11 \\
Once a fortnight & 0 & 2 & 1 \\
Once a month & 0 & 3 & 1 \\
\hline
\end{tabular}

Compared to the females, (42\%) the male $(65 \%)$ respondents consume fast food more frequently. Table 3 provides the details of mostly consumed fast foods by the students. Results show that mostly consumed fast foods are "Rolls" and "Wade". "Pastries" have become the third popular fast food. However, through the exploratory study, it is found out that "Vegetable Roti" is also one of the mostly consumed foods by university students. As per our study, food preferences of the 
science students may be greater for "Pastries" than "Vegetable Roti".

Table 3: Mostly consumed fast foods by respondents

\begin{tabular}{lcc}
\hline \multicolumn{1}{c}{\begin{tabular}{c} 
Name of Fast \\
\multicolumn{2}{c}{ food }
\end{tabular}} & \multicolumn{2}{c}{ Response (\%) } \\
& Yes & No \\
\hline Rolls & 45.7 & 54.3 \\
Pastries & 16.6 & 83.4 \\
Egg roti & 5.1 & 94.9 \\
Vegetable Roti & 8.6 & 91.4 \\
Wade & 25.1 & 74.9 \\
Patties & 13.1 & 86.9 \\
Fish Buns & 13.2 & 86.8 \\
Other & 53.7 & 46.3 \\
\hline
\end{tabular}

\section{Factors Considered When Buying Fast Foods}

For the question that was asked to list the most important three factors that they consider when buying fast food, the respondents had listed price $(39 \%)$, taste (38\%) and cleanliness of the outlet (12\%) as the most important three attributes for their selection (Table 4). Lee (2007) showed that the taste and low cost were the major reasons for patronizing fast food restaurants by elementary and high school students. People in their teen and twenties have listed fast service, convenience, taste and price, were the reasons for frequent buying of fast foods (Park et al., 1999).

\section{Relationship between a Student's Place of Living and Their Health Status}

Probability obtained according to the Kruskal Wallis test was 0.189 and is higher than 0.05 , indicating the acceptance of $\mathrm{H}_{0}$ hypothesis. Therefore, nutritional status of a student group does not differ based on the place of living. This test signifies that there is no effect of their place of living on students' nutritional status. Therefore, despite the place of residing, every student's diet consists of the same type of food resulting no difference in health status.

Table 4: Most important attribute when purchasing fast foods

\begin{tabular}{lc}
\hline Attribute & $\%$ \\
\hline Price & 39 \\
Taste & 38 \\
Size & 2 \\
Who sell foods/ name of & 6 \\
outlet & \\
Cleanliness of outlet & 12 \\
Healthiness & 2 \\
Speedy service & 1 \\
\hline
\end{tabular}

\section{Relationship between Student's Perception towards Their Diet and Their Actual Nutritional Status}

The details about the nutritional status of the students with their perception towards their own diet are shown in Table 5. Spearman's Rank Correlation Test showed a very weak positive correlation (0.050). However, this relationship is statistically insignificant showing $\mathrm{p} 0.491>0.05$ and thereby suggests that there is no clear relationship between the perception towards student's diet and their actual health status.

Among the students who think that their diet is healthy, only $69.6 \%$ are actually healthy (with $30.4 \%$ of both underweight 
and overweight). In addition, all the percentages of healthy students together even do not show any association with the diet. Hence, all the values indicate a nonexistence of a relationship between the perception towards the diet and the health status of the students.

\section{Relationship between Attitudes towards Fast Food Consumption and Gender}

Both Median Test and Mann-Whitney U Test resulted $\mathrm{p}$ values $(0.569$, and 0.369 , respectively) that were $>0$. Therefore, $\mathrm{H}_{0}$ hypothesis is accepted which confirms that there is no difference in attitudes depending on gender. Median test result accepts the $\mathrm{H}_{0}$ hypothesis tested more strongly than the Mann-Whitney U Test, may be due to the smaller sample size. However, since the attitudes score used for this test has a lower internal consistency (Cronbach's alpha) value, this result is less accurate and cannot be generalized.

Relationship between the Frequency of Fast Food Consumption and Nutritional Status

According to the percentages of students having different health status, it is shown that the number of healthy students increases with the reduction of the frequency of fast food consumption (amount of fast food that they consume) as indicated in Table 6. Not only the healthy students, but also the percentage of underweight students seems to decrease with the reduction of frequency of fast food consumption up to a certain extent.
Table 5: Comparison of perception towards the diet and actual health status

\begin{tabular}{llll}
\hline Perception & Health status & F & $\%$ \\
\hline Unhealthy & Underweight & 4 & 36.4 \\
& Normal & 6 & 54.5 \\
& Obese & 1 & 9.1 \\
Less & Total & 11 & 100.0 \\
healthy & Normal & 17 & 77.3 \\
& Overweight & 2 & 9.1 \\
Neutral & Total & 22 & 100.0 \\
& Normal & 54 & 80.6 \\
& Overweight & 2 & 3.0 \\
& Obese & 1 & 1.5 \\
Slightly & Underweight & 17 & 25.8 \\
Healthy & Normal & 40 & 60.6 \\
& Overweight & 9 & 13.6 \\
& & 66 & 100.0 \\
Healthy & Underweight & 3 & 13.0 \\
& Normal & 16 & 69.6 \\
& Overweight & 4 & 17.4 \\
& & 23 & 100.0 \\
\hline & & &
\end{tabular}

Note: $F=$ Frequency

In order to examine whether there is a correlation between the frequency of fast food consumption and student's health status, Spearman's Rank Order Correlation Test was applied and received a very weak negative relationship (-0.055) which was statistically insignificant at $\alpha=0.05$. This may be due to the lack of observations made to prove the relationship statistically. 
Table 6: Frequency of fast food consumption and nutritional status of respondents

\begin{tabular}{|c|c|c|c|}
\hline & & Frequency & $\%$ \\
\hline $2-3$ & Underweight & 11 & 28.9 \\
\hline times & Normal & 23 & 60.5 \\
\hline per & Overweight & 3 & 7.9 \\
\hline day & Obese & 1 & 2.6 \\
\hline \multirow{5}{*}{$\begin{array}{c}\text { Once a } \\
\text { day }\end{array}$} & Total & 38 & 100.0 \\
\hline & Underweight & 11 & 19.3 \\
\hline & Normal & 40 & 70.2 \\
\hline & Overweight & 6 & 10.5 \\
\hline & Total & 57 & 100.0 \\
\hline $4-6$ & Underweight & 3 & 16.7 \\
\hline times & Normal & 13 & 72.2 \\
\hline \multirow[t]{2}{*}{ a week } & Overweight & 2 & 11.1 \\
\hline & Total & 18 & 100.0 \\
\hline $2-3$ & Underweight & 7 & 14.9 \\
\hline times & Normal & 34 & 72.3 \\
\hline \multirow[t]{3}{*}{ a week } & Overweight & 5 & 10.6 \\
\hline & Obese & 1 & 2.1 \\
\hline & Total & 47 & 100.0 \\
\hline \multirow{4}{*}{$\begin{array}{c}\text { Once a } \\
\text { week }\end{array}$} & Underweight & 3 & 12.5 \\
\hline & Normal & 20 & 83.3 \\
\hline & Overweight & 1 & 4.2 \\
\hline & Total & 24 & 100.0 \\
\hline $\begin{array}{l}\text { Once } \\
\text { in } 14 \\
\text { days }\end{array}$ & Normal & 2 & 100.0 \\
\hline Once a & Underweight & 2 & 66.7 \\
\hline \multirow[t]{2}{*}{ month } & Normal & 1 & 33.3 \\
\hline & Total & 3 & 100.0 \\
\hline
\end{tabular}

\section{Relationship between BMI and Gender}

Median Test resulted a $\mathrm{p} 0.557>0.05$. This suggests accepting $\mathrm{H}_{0}$ hypothesis which says that the BMI of both male and female students are equal.

\section{Relationship between the Frequency of Fast Food Consumption and Gender}

The outcome of the Median Test $(\mathrm{p}<0.01)$ and Mann-Whitney U Tests $(\mathrm{p}<0.001)$ both reject $\mathrm{H}_{0}$ implying the acceptance of alternative hypothesis which says that there is a difference between the frequency of fast foods consumed among male and female students. Hence, there is a significant difference between the amount of fast food consumed among male and female students. According to the results, $41.8 \%$ female students and $65.0 \%$ of male students are daily consumers of fast food.

\section{Results of the Proximate Analysis of Selected Fast Foods}

The nutrient composition and the amount of dietary energy supplied by the selected fast foods, which are sold in the university canteens are given in Table 7. Higher amounts of total fat and protein are provided by "Wade" (16.68 g and $18.86 \mathrm{~g} / 100 \mathrm{~g}$ dry weight respectively) and "Egg Rolls" (10.55 g and $18.04 \mathrm{~g} / 100 \mathrm{~g}$ dry weight respectively) compared with other two types of foods namely "Vegetable Roti" and "Vegetable Rolls".

When considering about the diet of the university students, the majority of the students are daily consumers of fast foods who consume at least once a day. If a student consumes a fast food (Egg Rolls, Vegetable Rolls, Vegetable Roti or Wade), once a day, he/she will get $125.07 \pm 26.92$ kcal of dietary energy per unit (Calculation not shown). According to Ileperima (2005), 
Table 7. Nutrient composition and dietary energy supply of selected fast foods (100 g of dry weight basis)

\begin{tabular}{ccccccc}
\hline Sample & Total fat $(\mathrm{g})$ & Protein $(\mathrm{g})$ & Carbohydrate $\left(\mathrm{g}^{*}\right)$ & $\begin{array}{c}\text { Fibre } \\
(\mathrm{g})\end{array}$ & Ash $(\mathrm{g})$ & $\begin{array}{c}\text { Energy } \\
(\mathrm{kcal})\end{array}$ \\
\hline Egg Rolls & 18.04 & 10.55 & 48.97 & 19.21 & 3.23 & 207.97 \\
& $(9.37)$ & $(5.48)$ & $(25.43)$ & $(9.98)$ & $(1.68)$ & \\
Vegetable Rolls & 15.52 & 10.45 & 50.25 & 18.88 & 4.90 & 193.99 \\
& $(7.87)$ & $(5.3)$ & $(25.49)$ & $(9.58)$ & $(2.49)$ & \\
Vegetable Roti & 9.69 & 9.58 & 55.88 & 21.67 & 3.18 & 148.19 \\
& $(4.11)$ & $(4.07)$ & $(23.73)$ & $(9.2)$ & $(1.35)$ & \\
Wade & 18.86 & 16.68 & 39.25 & 19.86 & 5.35 & 288.94 \\
& $(13.7)$ & $(12.29)$ & $(29.12)$ & $(14.63)$ & $(3.94)$ & \\
\hline
\end{tabular}

Note: Values within brackets are per $100 \mathrm{~g}$ of wet weight basis;

*Carbohydrate by the "Difference" method; energy kcal/100 g wet weight basis.

students at the University of Sri Jayewardenepura can possibly achieve their daily energy requirement of approximately $2466 \mathrm{kcal}$ with $1801 \mathrm{kcal}$ from the assumed daily diet $+665 \mathrm{kcal}$ (provided by the lunch packets at the university canteens). WHO recommends the mean energy intake for a female and male population at the age group of 20 to 27 years is about $2300 \mathrm{kcal}$ per day (mean height of $1.59 \mathrm{~m} \&$ a lifestyle of active or moderately active with a Physical Activity Level value of 1.85) and $2800 \mathrm{kcal}$ per day (mean height of $1.71 \mathrm{~m} \&$ a lifestyle of active or moderately active) respectively.

If a university student gets approximately $2466 \mathrm{kcal}$ diet per day (Ileperima, 2005), only female students will be able to fulfill their daily energy requirement. For male students, another dietary energy source of about $334 \mathrm{kcal}$ is required to fulfill the requirement. The findings of this study statistically prove that there is a significant difference between the amounts of fast foods consumed (frequency of consumption) by male and female students. The frequency of fast food consumption is much higher among male students than female students. This signifies that male students are depending on additional dietary energy sources like fast food to fulfill their daily energy requirement.

If a student consumed one unit of one of the above mentioned fast foods once a day, he/she would be able to gain 125.07 $\pm 26.92 \mathrm{kcal}$ (maximum $151.99 \mathrm{kcal}$ ) (calculation is not shown here). It provides dietary energy of $2617.99 \mathrm{kcal}$ (i.e. $2466+$ $151.99 \mathrm{kcal}$ ) in total. Even though it is more than enough for the daily intake of a female student, it is not sufficient for male students. Therefore, they have to consume foods more than once a day. Possible option for male students is fast foods. However, consumption of additional foods totally depends on the purchasing power of the 
students. The findings suggest that the main factors they consider when purchasing fast foods are price and taste (Table 4).

Despite the fact that the diet is not enough to fulfill the students' daily energy requirement, a higher prevalence of overweight $(12 \%)$ was recorded among male students which is greater than that among female students (7\%). Even though the diet of female students is sufficient for their daily requirements, a higher prevalence of underweight condition (26\%) was reported among female students than among male students (9\%).

According to FAO (2003), the adult population group in Sri Lanka is affected by under nutrition as indicated by the prevalence of chronic energy deficiency (CED) which is more than $33 \%$ in women and nearly $37 \%$ in men. The high prevalence of under nutrition in the adult population limits their work output, productivity and income-generating ability. Desegregated data show that $9 \%$ of the female population in Sri Lanka suffers from severe CED with a BMI value $<16.0 \mathrm{~kg} / \mathrm{m}^{2}$, while one quarter of women population has a BMI between 16.0 and $18.5 \mathrm{~kg} / \mathrm{m}^{2}$ and therefore suffers from mild and moderate CED. Although the prevalence of severe CED is slightly lower in men (5\%), overall, $37 \%$ of men suffer from CED (BMI<.18.5 $\mathrm{kg} / \mathrm{m} 2$ ) (FAO, 2011). Our result on BMI shows that female students in the faculty are suffering from mild and moderate CED as their average $\mathrm{BMI}$ is equal to $20.56 \pm 3.35$ (Table 1).
According to the literature, respondents tend to underestimate the amount of food that they consume when they are asked to recall (Dunn et al., 2011). Therefore, despite the fact that the energy supplied by their daily diet is inadequate, students consume fast foods more than they reported to the questionnaire resulting in prevalence of higher percentage of overweight condition among male students. Hence, male students are more likely to associate with overweight and obesity related NCDs than female students. On the other hand, some female students are more likely to have complications due to underweight conditions and the likelihood of being affected by diseases is higher for them.

\section{CONCLUSION}

Results of this study provide an insight to the fast food consumption behaviors of the faculty students and its relationship with their nutritional status. "Rolls", "Wade" and "Pastries" are the mostly consumed fast foods by respondents and contain high amounts of total fat, protein and carbohydrates. Many students (54\%) consume fast foods more than once a day. Price and taste are the major attributes used for selecting a fast food. The majority (70\%) of the students are healthy having a normal BMI. A significantly higher amount of fast food is consumed by male students than female students. There is a higher tendency of male students to be affected by diet related NCDs due to the higher prevalence of overweight among them. 


\section{REFERENCES}

Afolabi, W.A.O., Oyawoye, O.O., Sanni, S.A. and Onabanjo, O.O. (2013). Proximate and cholesterol composition of selected fast foods sold in Nigeria. Nigerian Food Journal, 31: 70- 76.

Alfawaz, H.A. (2012). The relationship between fast food consumption and BMI among university female students. Pakistan Journal of Nutrition, 11 (5): 406- 410.

Almiron-Roig E., lis-Trapala I., Dodd J. and Jebb S.A. (2013). Estimating food portions, influence of unit number, meal type and energy density. Appetite, 71 (1): 95- 103.

Akindutire, I.O. and Konwea, P.E. (2013). Consumption of fast food and dietary self-efficacy of university undergraduates in Nigeria. International Journal of Health Promotion and Education, 51 (3): 144- 150.

Arulogun, O.S. and Owolabi, O. (2011). Fast food consumption pattern among undergraduates of the University of Ibadan, Nigeria: implications for nutrition education. Journal of Agriculture and Food Technology, 1: 89- 93.

Cotti, C. and Tefft, N. (2013). Fast food prices, obesity and the minimum wage. Economics \& Human Biology, 11: 134- 147.

Currie, J., Dellavigna, S., Moretti, E. and Pathania, V. (2010). The effect of fast food restaurants on obesity and weight gain. American Economic Journal: Economic Policy, 2: 3263.

Danowska-Oziewicz, M., Spiel, J. and Karpińska-Tymoszczyk, M. (2012). Socio-demographic determinants of fast food eating among the students of the University of Warmia and Mazury in Olsztyn. Polish Journal of Natural Sciences, 27 (4): 477490.

Deliens, T., Clarys, P., De Bourdeaudhuij, L. and Deforche, B. (2013). Weight, socio-demographics, and health behaviour related correlates of academic performance in first year university students. Nutrition Journal, 12: 162.

DOI: $10.1186 / 1475-2891-12-162$

Dunn, K.I., Mohr, P., Wilson, C.J. and Wittert, G.A. (2011). Determinants of fast-food consumption. An application of Theory of Planned Behavior. Appetite, 57 (2): 349357.

Dunn R.A., Sharkey, J.R. and Horel, S. (2012). The effect of fast food availability on fast food consumption and obesity among rural residents; An analysis by race/ ethnicity. Economics and Human Biology, 10 (1): 1- 13.

El Ansari, W., Stock, C. and Mikolajczyk, R.T. (2012). Relationships between food consumption and living arrangements among university students in four European countries - a cross-sectional study. Nutrition Journal, 11: 28. 
Finer, N. (2011). Medical consequences of obesity. Medicine, 39, 18- 23.

Food and Agricultural Organization, (2003). Diet, Nutrition and Prevention of Chronic Diseases. Report of a joint WHO/FAO expert consultation. Genveva.

Food and Agricultural Organization. (2011). Nutrition Country ProfileSri Lanka. http://www.fao.org/ag/agn/nutrition /srl_en.stm

Ileperima, N., (2005). Proximate analysis of lunch packets supplied to the university students through university canteens. MSc Thesis. University of Sri Jayewardenepura, Nugegoda, Sri Lanka.

Khatib, O. (2004). Noncommunicable disease: Risk factors and regional strategies for prevention and care. Eastern Mediterranean Health Journal, 10 (6): 778- 788.

Kearney, J. (2010). Food consumption trends and drivers. Philosophical transactions of the royal society $B$ : biological sciences, 365: 27932807.

Kobayashi, F. (2009). Academic achievement, BMI, and fast food intake of American and Japanese college students. Nutrition and Food Science, 39 (5): 555- 566.

Laska, M.N., Larson, N.I., NeumarkSztainer, D. and Story, M. (2010). Dietary patterns and home food availability during emerging adulthood: Do they differ by living situation? Public Health Nutrition, 13: 222- 228.
Laska, M.N., Larson, N.I., NeumarkSztainer, D. and Story, M. (2012). Does involvement in food preparation track from adolescence to young adulthood and is it associated with better dietary quality? Findings from a 10-year longitudinal study. Public Health Nutrition, 15: 1150- 1158.

Lee, J.S. (2007). A comparative study on fast food consumption patterns classified by age in Busan. Korean Journal of Community Nutrition, 12: 534- 544.

Park, M.R., Kim, S.H. and Wi, S.U., (1999). The consumption patterns of fast foods in small cities. Korean Journal of Food Cult., 14: 139- 146.

Mihalopoulos, N. L., Auinger, P. and Klein, J. D. (2008). The freshman 15: Is it real? Journal of American College Health, 56: 531- 533.

Onurlubaş, E. and Yilmaz, N. (2013). Fast food consumption habits of university students. Journal of Food, Agriculture and Environment, 11 (3- 4): 12- 14.

Pereira, M.A., Kartashov, A.I., Ebbeling, C.B., Van horn, L., Slattery, M.L., Jacobs Jr., D.R. and Ludwig, D.S. (2005). Fast-food habits, weight gain, and insulin resistance (the CARDIA study): 15-year prospective analysis. Lancet, 365: 36- 42.

Rocha, C.A.V., De Arvelos, L. R., Felix, G. P., De Souza, D.N.P., Neto, M.B., Santos Resende, E. and Penha-silva, N. (2012). Evolution of nutritional, hematologic and biochemical 
changes in obese women during 8 weeks after Roux-en-Y gastric bypass. Nutricion Hospitalaria. 27: 1134- 1140.

Roe M., Pinchen,H., Church S., Elahi S., Walker M., Farron-Wilson M., Buttriss J. and Finglas P. (2013). Trans fatty acids in a range of UK processed foods. Food Chemistry, 140 (3): 427- 431.

Sim, K.H. and Kim, S.A. (1993). Utilization state of fast foods among Korean youth in big cities. Korean Journal of Nutrition, 26: 804- 811.

Seo, H.S., Lee, S.K. and Nam, S. (2011). Factors influencing fast food consumption behaviors of middleschool students in Seoul: an application of theory of planned behaviors. Nutrition Research and Practice. 5: 169- 178.

Trichopoulou, A., Naska, A., Antoniou, A., Friel, S., Trygg, K., and Turrini, A. (2003). Vegetable and fruit: The evidence in their favor and the public health perspective. International Journal for Vitamin and Nutrition Research, 73: 63- 69.

WHO (2004) World Health Organization expert consultation. Appropriate body-mass index for Asian populations and its implications for policy and intervention strategies. The Lancet: 157-163.

WHO (2014), World Health Organization, Sri Lanka Country Profile. http://www.who.int/nmh/countries/ lkaen.pdf

Wilcox, S., Sharpe, P.A., TurnerMcGrievy, G., Granner, M. and
Baruth, M. (2013). Frequency of consumption at fast-food restaurants is associated with dietary intake in overweight and obese women recruited from financially disadvantaged neighborhoods. Nutrition Research, 33 (8): 636646.

Wellard L., Glasson C. and Chapman K. (2012). Fries or a fruit bag? Investigating the nutritional composition of fast food children's meals. Appetite, 58 (1): 105- 110.

Yardimci, H., Ozdogan, Y., Ozcelik, A.O. and Surucuoglu, M.S. (2012). Fastfood consumption habits of university students: The sample of Ankara. Pakistan Journal of Nutrition, 11 (3): 265- 269. 